\title{
PENILAIAN POTENSI OBJEK WISATA AIR TERJUN SARAY BRUNYAU DESA RIAM PIYANG KECAMATAN BUNUT HULU KABUPATEN KAPUAS HULU
}

\author{
Assessment of the potential tourist attraction of Saray Brunyau Waterfall, Riam Piyang Village, \\ Bunut Hulu District, Kapuas Hulu Regency
}

\section{Sarma Siahaan ${ }^{*}$, Reine Suci Wulandari, Fahrid Mizwar}

Fakultas Kehutanan, Universitas Tanjungpura, Jalan Imam Bonjol, Pontianak 78124

*Email : sarma@fahutan.untan.ac.id

Diterima : 03/09/2021, Direvisi : 13/12/2021, Disetujui : 08/01/2022

\begin{abstract}
Kapuas Hulu Regency is an area that has a variety of flora and fauna and has natural wealth and natural beauty that has the potential as a tourist attraction so that it must be developed, one of which is Saray Brunyau Waterfall in the forest area of Riam Piyang Village, Bunut Hulu District, Kapuas Hulu Regency. Saray Brunyau Waterfall has the potential to be used as a tourist spot because the area has natural beauty and unspoiled scenery and has a natural panorama consisting of trees such as meranti trees (Shorea spp.), rengas trees (Gluta renghas, $L$ ) and many animals. wild animals such as monkeys, lempiau and other wildlife that adorn the waterfall area itself. Therefore Saray Brunyau Waterfall needs to be used as a place of research to get its potential value so that its feasibility can be known or developed into a tourist destination. The purpose of the study was to obtain the value of the potential attraction of Saray Brunyau Waterfall. The research method is survey and direct observation in the field as well as conducting interviews with questionnaires using accidental sampling techniques to determine respondents, and giving an assessment of each element and sub-element using the 2003 PHKA ODTWA assessment guideline. The elements assessed are tourist attraction, accessibility, accommodation., supporting infrastructure, regional security, and the availability of clean water. The results of the overall score get a total value of $2432 / 5=486.4$ or fall into the classification category $(B)$ meaning that it is quite potential to be developed into a tourist destination.
\end{abstract}

Keywords: ecotourism; tourism potential; cascade of bananas

\begin{abstract}
ABSTRAK
Kabupaten Kapuas Hulu merupakan daerah yang mempunyai beranekaragam flora dan fauna serta memiliki kekayaan alam dan keindahan alam yang berpotensi sebagai objek wisata sehingga harus di kembangkan, salah satunya adalah Air Terjun Saray Brunyau pada kawasan hutan desa Riam Piyang Kecamatan Bunut Hulu, Kabupaten Kapuas Hulu. Tujuan penelitian adalah mendapatkan nilai potensi daya Tarik Air Terjun Saray Brunyau. Metode penelitian adalah dengan surve dan observasi langsung dilapangan serta melakukan wawancara dengan kuesioner menggunakan teknik accidental sampling untuk menentukan
\end{abstract}


responden, dan memberi penilaian pada setiap unsur serta sub unsur yang menggunakan pedoman penilaian ODTWA PHKA 2003. Unsur yang dinilai seperti daya Tarik wisata, aksesibilitas, akomodasi, sarana prasarana penunjang, keamanan kawasan, dan ketersediaan air bersih. Hasil nilai keseluruhan mendapat nilai total sebesar 2432/5 = 486,4 atau masuk kedalam kategori klasifikasi (B) artinya cukup potensial dikembangkan menjadi destinasi wisata.

Kata kunci: ekowisata; potensi wisata; riam piyang

\section{PENDAHULUAN}

Kabupaten Kapuas Hulu merupakan daerah yang memiliki kekayaan alam berupa flora dan fauna yang berpotensi sebagai objek wisata. Potensi tersebut perlu di kembangkan dan dikelola dengan baik untuk kepentingan masyarakat dengan memperhatikan aspek konservasi sehingga keseimbangan, perlindungan dan pemanfaatan dapat terjaga dan lestari. Saat ini objek wisata Saray Brunyai sering dikunjungi wisatawan baik dari dalam maupun dari luar daerah, namun permasalahannya, pengunjung masih belum mendapatkan kepuasan karena data tentang informasi objek secara detail belum diperoleh. Dasar untuk pengembangan destinasi wisata perlu dilakukan penilaian potensi dan ketersediaan data, informasi secara ilmiah untuk pengembangan atau pengelolaan objek wisata dengan penilaian

khas suatu daerah memiliki kekayaan tertentu berupa potensi alam, adat istiadat, dan kemampuan masyarakat yang berbeda-beda, sesuai dengan kondisi geografis seperti bentang alam (Aditiawati et al., 2016). Kondisi alam yang berbeda dapat menyebabkan adanya keistimewaan pada daerah, ciri khas panorama, budaya masyarakat dan perilaku, serta kemakmuran penduduk juga dapat membuat hubungan yang saling terkait. Ketiga unsur tersebut merupakan hal yang penting untuk di perhatikan dalam pebangunan dan pengembangan potensi daerah (Paramita et al., 2018).

Berdasarkan data dari Dinas Komunikasi, Informatika dan Statistik Kabupaten Kapuas Hulu (2021) bahwa Kabupaten Kapuas Hulu memiliki 25 obyek wisata yang berbeda-beda mulai dari wisata alam, wisata buatan, wisata budaya dan wisata religi, namun belum dikelola dengan baik. salah satunya adalah Air Terjun Saray Brunyau yang berada didalam kawasan hutan desa tepatnya Desa Riam Piyang Kecamatan Bunut Hulu Kabupaten Kapuas Hulu.

Menurut penelitian Erni (2018), nilai potensi obyek dan atraksi wisata alam Taman Nasional Betung Kerihun dan Taman Nasional Danau Sentarum di Kabupaten Kapuas Hulu bahwa kawasan ini layak untuk dikembangkan sebagai destinasi ekowisata dengan indeks nilai potensi kelayakan sebesar $78.20 \%$. Begitu juga dalam penelitian Lidia (2016) didapatkan nilai untuk kriteria daya Tarik obyek wisata danau mupa kencana di Kecamatan Putussibau Utara Kabupaten Kapuas Hulu sebesar 741,98 (B) yang berarti Danau Mupa Kencana cukup potensial dikembangkan sebagai tempat/obyek wisata alam.

Penelitian ini bertujuan untuk mendapatkan nilai potensi daya tarik objek wisata Air Terjun Saray Brunyau Desa Riam Piyang Kecamatan Bunut Hulu, Kabupaten Kapuas Hulu.

\section{METODE}

Penelitian dilaksanakan di Desa Riam Piyang Kecamatan Bunut Hulu Kabupaten Kapuas Hulu. Waktu penelitian yang digunakan adalah selama 2 bulan, mulai dari bulan Mei 
sampai dengan bulan Juli 2021. Metode penelitian yang digunakan adalah metode survey dengan tehnik wawacara menggunakan bantuan kuisioner, selanjutnya melakukan observasi langsung ke lapangan untuk menggali potensi daya tarik wisata sesuai dengan informasi yang diperoleh pada saat wawancara. Teknik pengambilan respoden dilakukan dengan accidental sampling atau siapa saja wisatawan yang berkunjung akan dijadikan responden sesuai dengan kriteria yang sudah ditentukan, sedangkan untuk responden dari masyarakat dan stake holder ditentukan secara purposive sampling. Alat dan bahan pada penelitian ini adalah perekam suara, kamera, kuesioner sebagai instrument pengambilan data primer dilapangan dan pedoman ODTWA PHKA 2003.

Analisis data menggunakan analisis deskriptif untuk data-data yang telah terkumpul serta penilaian daya tarik objek wisata, aksesibilitas, akomodasi, sarana prasana dan ketersediaan air bersih mengacu pada pedoman ODTWA PHKA 2003, selanjutya dimodifikasi dengan hasil penelitian yang diperoleh, sehingga mendapatkan nilai kategori baik atau potensial dikembangkan (A), sedang atau cukup potensial dikebangkan (B) dan buruk atau tidak potensial dikembangkan (C). Modifikasi kriteria penilaian didapat dari penjumlahan masing-masing nilai maksimum dan minimum pada setiap nilai bobot. Selanjutnya hasil penjumlahan nilai tersebut dikurangi sehingga diproleh nilai range dan dibagi tiga kelas penilaian potensi unsur. Hasil total skor penilaian dibagi dengan lima kriteria penilaian dan dibandingkan kedalam tabel modifikasi ODTWA PHKA 2003. Berikut tabel modifikasi kriteria unsur penilaian:

\section{Daya Tarik Wisata}

Objek wisata air terjun Saray Brunyau memiliki potensi daya Tarik wisata dengan kriteria bobot maksimum dan minimum yang dibagi menjadi tiga kelas yaitu baik, sedang dan buruk. Kriteria penilaian dapat dilihat pada table 1.

Tabel 1. Modifikasi Nilai Bobot Kriteria Penilaian Daya Tarik Wisata Table 1. Modification of the Weight Value of the Criteria for Assessment of Tourist Attractions

\section{No. Daya Tarik wisata Penilaian potensi unsur}

$\begin{array}{lll}\text { 1. } & \geq 1120-1440 & \text { Baik (A) } \\ \text { 2. } & \geq 800-1120 & \text { Sedang (B) } \\ \text { 3. } & 480-800 & \text { Buruk (C) }\end{array}$

Sumber: Modifikasi Nilai Daya Tarik Obyek Wisata Alam PHKA Tahun 2003

\section{Aksesibilitas}

Aksesibilitas menuju air terjun Saray Brunyau memiliki nilai bobot kriteria pada kategori buruk ( C ) dapat dilihat pada table 2 .

Tabel 2. Klasifikasi Pengembangan Berdasarkan Nilai Bobot Kriteria Penilaian Aksesibilitas

Table 2. Development Classification Based on Weight Value of Accessibility Assessment Criteria

\begin{tabular}{cll}
\hline No. Aksesibilitas & Penilaian potensi unsur \\
\hline 1. & $\geq 469-651$ & Baik $(\mathrm{A})$
\end{tabular}




$\begin{array}{lcl}2 . & \geq 287-469 & \text { Sedang (B) } \\ 3 . & 105-287 & \text { Buruk (C) }\end{array}$

Sumber: Modifikasi Aksesibilitas Obyek Wisata Alam PHKA Tahun 2003

\section{Akomodasi}

Nilai akomodasi kawasan Air terjun Saray Brunyau memiliki nilai C, yang berarti buruk seperti pada table 3 berikut :

Tabel 3. Klasifikasi Pengembangan Berdasarkan Nilai Bobot Kriteria Penilaian Akomodasi

Table 3. Classification of Development Based on Weight Value of Accommodation Assessment Criteria

\begin{tabular}{ccl}
\hline No. & Akomodasi & Penilaian potensi unsur \\
\hline 1. & $\geq 135-165$ & Baik (A) \\
2. & $\geq 105-135$ & Sedang (B) \\
3. & $75-105$ & Buruk (C)
\end{tabular}

Sumber: Modifikasi Buku Biru (Sasaran Ukuran Pembinaan Pengembangan Obyek Wisata Alam PHKA Tahun 2003

\section{Sarana dan Prasarana Penunjang}

Perolehan nilai sarana dan prasarana penunjang setelah dimodifikasi pada kriteria penilaian PHKA 2003 masuk pada kategori baik ( A ), artinya potensial dijadikan sebagai tempat rekreasi. Hasil sarana dan prasarana dilihat pada table 4.

Tabel 4. Klasifikasi Pengembangan Berdasarkan Nilai Bobot Kriteria Penilaian Sarana dan Prasarana

Table 4. Development Classification Based on Weight Value of Facilities and Infrastructure Assessment Criteria

No. Sarana dan Prasarana Penilaian potensi unsur

$\begin{array}{lcl}1 . & \geq 135-180 & \text { Baik (A) } \\ 2 . & \geq 90-135 & \text { Sedang (B) } \\ 3 . & 45-90 & \text { Buruk (C) }\end{array}$

Sumber: Modifikasi Buku Biru (Sasaran Ukuran Pembinaan Pengembangan Obyek Wisata Alam PHKA Tahun 2003

\section{Ketersediaan Air Bersih}

Hasil pengamatan langsung, kriteria ketersediaan air bersih memiliki nilai skor sebesar 870 . Klasifikasi ketersediaan air bersih berada pada kategori baik (A), air bersih dapat ditemukan pada jarak 0-1 km sehingga layak untuk dikembangkan. Hasil ketersediaan air dapat dilihat pada table 5. 
Tabel 5. Klasifikasi Pengembangan Berdasarkan Nilai Bobot Kriteria Ketersediaan air bersih

Table 5. Development Classification Based on Weight Value Criteria for Availability of clean water

\begin{tabular}{ccl}
\hline No. & Ketersediaan air bersih & Penilaian potensi unsur \\
\hline 1. & $\geq 690-900$ & Baik (A) \\
2. & $\geq 480-690$ & Sedang (B) \\
3. & $270-480$ & Buruk (C)
\end{tabular}

Sumber: Modifikasi Buku Biru (Sasaran Ukuran Pembinaan Pengembangan Obyek Wisata Alam PHKA Tahun 2003

Hasil klasifikasi unsur dan sub unsur lima kriteria penilaian yaitu daya Tarik wisata, aksesibiltas, akomodasi, sarana dan prasarana dan ketersediaan air bersih mendapatkan nilai ( B ), artinya air terjun Saray Brunyau cukup potensial dikembangkan sebagai destinasi wisata alam. Hasil penilaian disajikan pada tabel 6.

Tabel 6. Klasifikasi Pengembangan Berdasarkan Nilai Total Bobot Setiap Kriteria Penilaian

Table 6. Development Classification Based on the Total Weight Value of Each Assessment Criterion

\begin{tabular}{cll}
\hline No. & Nilai Total & Penilaian potensi unsur \\
\hline 1. & $\geq 509-666$ & Potensial dikembangkan (A) \\
2. & $\geq 352-509$ & Cukup potensial dikembangkan (B) \\
3. & $195-352$ & Tidak potensial dikembangkan (C)
\end{tabular}

Sumber: Modifikasi Buku Biru (Sasaran Ukuran Pembinaan Pengembangan Obyek Wisata Alam PHKA Tahun 2003

Penilaian bobot total dari setiap klasifikasi penilaian potensi objek wisata kemudian di bagi menjadi tiga yaitu potensial dikembangkan, cukup potensial dikembangkan dan tidak potensial dikembangkan. Nilai potensial dikembangkan berkisar antara $\geq 509-666$, nilai cukup potensial $\geq 352-509$, nilai tidak potensial $195-352$. Nilai tersebut di dapatkan dari rata-rata masing-masing klasifikasi kriteria penilaian kelas potensial, cukup potensial, dan tidak potensial.

\section{HASIL DAN PEMBAHASAN}

\section{Kriteria penilaian daya Tarik wisata}

Hasil perhitungan semua unsur kriteria penilaian potensi objek daya tarik wisata alam Air Terjun Saray Brunyau di Desa Riam Piyang Kecamatan Bunut Hulu Kabupaten Kapuas Hulu dilihat pada gambar 1. 


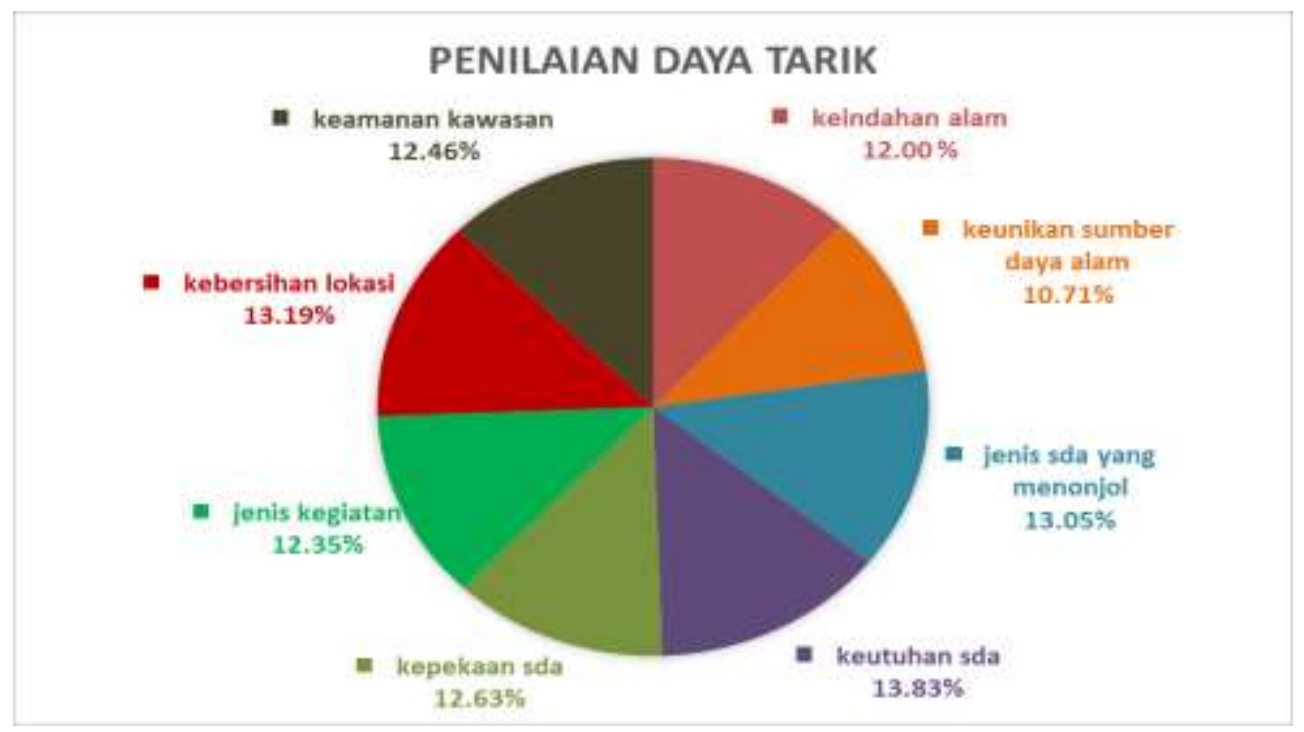

Gambar 1. Diagram hasil perhitungan kriteria potensi penilaian daya tarik wisata alam air terjun Saray Brunyau

Figure 1. Diagram of the calculation results of potential criteria for assessing natural tourist attraction of Saray Brunyau waterfall

Berdasarkan gambar nilai kriteria potensi yang tertinggi diperoleh pada unsur keutuhan sumberdaya alam (13.83\%) dan nilai terendah terdapat pada unsur keunikan (10.71\%), namun nilai keseluruhan sub unsur adalah 1037 artinya mempunyai daya Tarik yang tinggi. Devy et al., (2017) keberadaan potensi serta daya Tarik yang dimiliki suatu lokasi objek wisata menjadi faktor penting bagi pengunjung. Menurut Wawan. (2011), bahwa segala sesuatu yang mempunyai daya tarik tinggi dapat menjadi tujuan wisatawan ke suatu daerah tertentu. Undangundang No.10 Pasal 1. (2009) tentang daya Tarik wisata adalah segala sesuatu yang memiliki keindahan dan nilai yang berupa keanekaragaman kekayaan alam.

\section{Kriteria Penilaian Aksesibilitas}

Berdasarkan hasil penelitian terhadap penilaian kriteria aksesbilitas untuk unsur dan sub unsurnya diperoleh nilai 60 yang dikalikan dengan nilai bobot, sehingga nilai kriteria aksesibilitas di kawasan Air Terjun Saray Brunyau menjadi $60 \times 5=300$. Hasil perbandingan menunjukan bahwa kawasan Air Terjun Saray Brunyau memiliki aksesibilitas dengan nilai (B) yang berarti sedang untuk dikembangkan sebagai obyek wisata alam.

Menurut Sumarabawa et al., (2013) aksesibilitas merupakan sarana transportasi dan infrastruktur penunjang yang menjamin pengunjung lebih mudah dapat sampai dilokasi wisata. Akses jalan yang baik membuat pengunjung lebih puas dan tidak membosankan terlebih jika difasilitasi dengan trasportasi yang memadai. Untuk mewujudkan aksesibilitas yang menunjang dalam objek wisata dibutuhkan kerjasama antar seluruh pemangku wisata (Eichhorn et al., 2011).

Menurut data hasil observasi dilapangan kondisi jalan dari pusat Kota Putussibau menuju desa Riam Piyang sangat baik dengan lebar jalan 5 meter dan $75 \%$ jalan sudah di aspal, namun jalan menuju objek wisata hanya dapat dilalui dengan sepeda motor, memiliki bebatuan dan tanah, Jarak tempuh dari Kota Putussibau ke Desa Riam Piyang kurang lebih 98 
$\mathrm{Km}$ atau 2 jam melalui perjalanan darat pakai sepeda motor. Gambar aksessibilitas seperti pada Gambar 1.

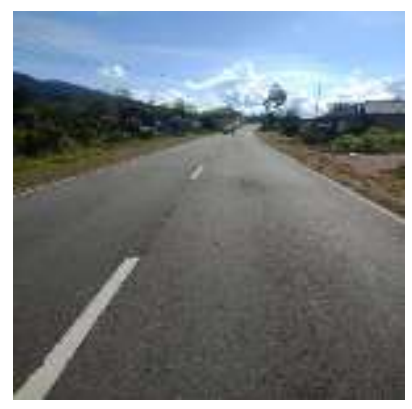

(a)

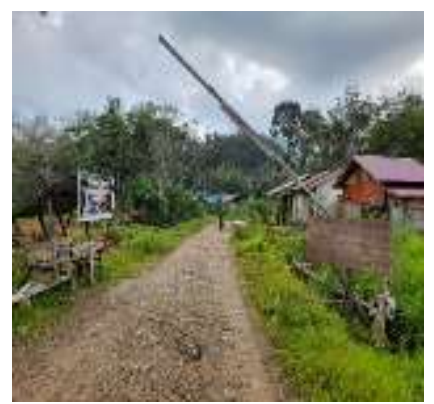

(b)

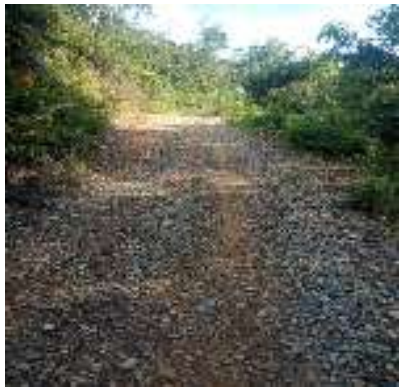

(c)

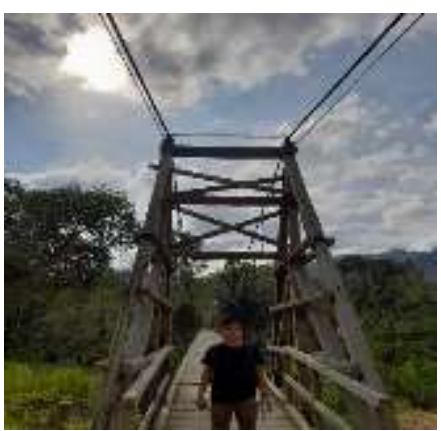

(d)

Gambar 2. Akses menuju kawasan air terjun saray brunyau (a) Jalan dari pusat kota Putusibau menuju kawasan air terjun, (b) pintu masuk menuju air terjun saray brunyau, (c) kondisi jalan dikawasan air terjun saray brunyau dan (d) jembatan gantung menuju kawasan air terjun saray brunyau.

Figure 2. Access to the saray brunyau waterfall area (a) the road to the waterfall area from the city center, (b) the entrance to the saray brunyau waterfall, (c) road conditions in the saray

brunyau waterfall area and (d) the suspension bridge area Saray Brunyau Waterfall.

\section{Kriteria Penilaian Akomodasi}

Hasil penilaian akomodasi diperoleh 15 artinya jumlah penginapan berada pada rentang 3-5 dengan jumlah kamar berada pada rentang 30 yang berarti nilainya 10 . Berdasarkan hasil perhitungan kriteria Penilaian Akomodasi memiliki total nilai 25. Nilai hasil pehitungan dikalikan dengan nilai bobot (3) menjadi $25 \times 3=75$. Akomodasi dan sarana prasarana diberi bobot 3 karena merupakan faktor penunjang dalam kegiatan wisata (Maharani, 2016), hasil perkalian dengan nilai bobot tersebut dibandingkan dengan modifikasi kriteria penilaian ODTWA PHKA 2003, sehingga akomodasi pada kawasan Air Terjun Saray Brunyau memiliki nilai (C) yang berarti buruk, Karsudi et al., (2010) menyatakan bahwa suatu obyek wisata dapat dikembangkan dengan melakukan promosi dan pemasaran, memperkecil kendala aksesibilitas, memperbaiki manajemen pengelolaan dan meningkatkan jasa pelayanan kepada pengunjung.

\section{Kriteria Penilaian Sarana dan Prasarana Penunjang}

Menurut ghani (2015) Sarana prasarana merupakan suatu infrastruktur yang mempermudah wisatawan selama berada di lokasi wisata. Zaenuri (2012) mengatakan Wisatawan akan berkunjung kembali apabila sarana dan parasarana penunjang serta fasilitas didalam objek wisata tersebut memadai. Berdasarkan hasil pengamatan dan penilaian langsung 
dilapangan kriteria sarana dan prasarana berada dalam jangkauan $13 \mathrm{~km}$ sehingga unsur prasarananya $\geq 4$ yang berarti nilainya 30 , dan unsur sarana penunjang nilainya 20 . Total nilai sarana dan prasarana adalah 50 yang dikalikan dengan nilai bobot (3) maka perolehan nilai menjadi 50 × $3=150$, diklasifikasikan pada modifikasi kriteria penilaian PHKA 2003 masuk pada kategori Baik $(A)$ berarti potensial dijadikan sebagai tempat rekreasi.

\section{Kriteria Ketersediaan Air Bersih}

Nilai hasil penelitiaan pada kriteria ketersediaan air bersih sebesar 145 , kemudian dikali dengan bobot nilai (6) sehingga menjadi $145 \times 6=870$. Hasil nilai menunjukan bahwa ketersediaan air bersih dikawasan Air Terjun Saray Brunyau dapat diklasifikasikan dlam kategori baik $(A)$ karena sumber air bersih dapat ditemukan pada jarak 0-1 km sehinga layak untuk di kembangkan sebagai tempat wisata alam. Saparuddin (2010) menyatakan bahwa selain debit air besar, lebih penting lagi kualitas air yang bersih atau sesuai standar. Ketersediaan air diharapkan dapat mengimbangi kebutuhuan air yang cukup (Yuliani et al., 2014). Ketersediaan air bersih dikawasan air terjun saray brunyau dapat dilihat pada Gambar 2.

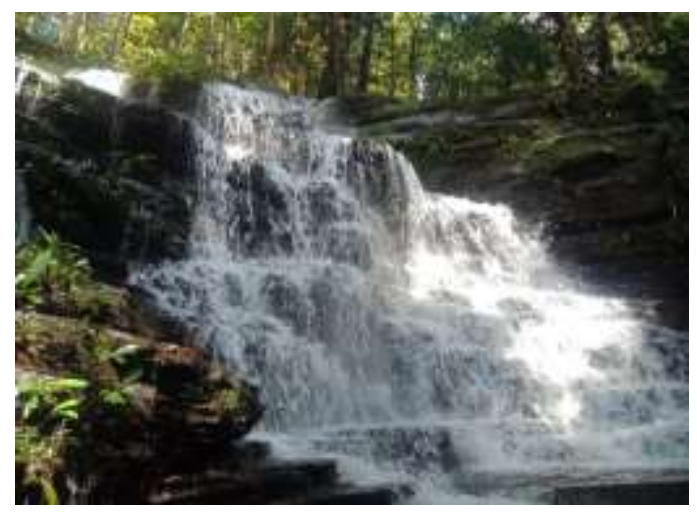

Gambar 3. Air Bersih

Figure 3. Clean Water

\section{Klasifikasi Hasil Perhitungan Unsur Pengembangan Sesuai dengan Nilai Bobot Setiap Kriteria Penilaian}

Perhitungan berdasarkan penilaian serta analisis data dari lima (5) kriteria penilaian adalah 2432, dapat dilhat pada tabel 7.

Tabel 7. Hasil Perhitungan Setiap Kriteria Penilaian Mengacu pada Standar Baku Klasifikasi Pengembangan ODTWA PHKA tahun 2003

Table 7. The Calculation Results of Each Assessment Criteria Refer to the Standard Standard 2003 PHKA ODTWA Development Classification

\begin{tabular}{clcl}
\hline No & \multicolumn{1}{c}{ Kriteria Penilaian } & Nilai & Klasifikasi \\
\hline 1 & Daya Tarik Wisata & 1037 & (B) Sedang \\
\hline 2 & Aksesibilitas & 300 & (B) Sedang \\
\hline 3 & Akomodasi & 75 & (C) Buruk \\
\hline 4 & Sarana Prasarana Pengunjung & 150 & (A) Baik \\
\hline 5 & Ketersediaan Air Bersih & 870 & (A) Baik \\
\hline & Skor Total Penilaian 2432 / $\mathbf{5 = 4 8 6 , 4}$ & & (B) Cukup Potensial Dikembangkan
\end{tabular}

Sumber: Hasil Penelitian, 2021 
Total nilai yang telah didapat adalah 486,4. Hasil modifikasi kriteria penilaian dinyatakan bahwa kawasan Air Terjun Saray Brunyau masuk ke dalam nilai klasifikasi B ( $\geq 352-509)$, artinya cukup berpotensi dikembangakan menjadi objek wisata alam. Modifikasi kriteria penilaian dilihat pada tabel 8.

Tabel 8. Klasifikasi Pengembangan Berdasarkan Nilai Total Bobot Setiap Kriteria Penilaian

Table 8. Development Classification Based on the Total Weight Value of Each Assessment Criterion

\begin{tabular}{ccl}
\hline No. & Nilai Total & Penilaian potensi unsur \\
\hline 1. & $\geq 509-666$ & Potensial dikembangkan $(\mathrm{A})$ \\
2. & $\geq 352-509$ & Cukup potensi dikembangkan (B) \\
3. & $195-352$ & Kurang potensial dikembangkan (C)
\end{tabular}

Sumber: Modifikasi Sasaran Ukuran Pembinaan Pengembangan Obyek Wisata Alam PHKA Tahun 2003

\section{KESIMPULAN DAN SARAN}

Hasil penelitian dari semua unsur dan sub unsur objek wisata didapatkan nilai sebesar 486,4 atau masuk pada klasifikasi B ( $\geq 352-509)$, artinya cukup potensial untuk dikembangkan menjadi objek wisata alam. Suatu destinasi wisata sangat diharapkan kerja sama antara pengelola dengan pemerintah daerah dalam menjaga kelestarian hutan serta potensi yang terdapat pada kawasan Air Terjun Saray Brunyau dan dapat bersama-sama untuk mengembangkan objek wisata Air Terjun Saray Brunyau dengan memperhatikan akomodasi agar memudahkan wisatawan untuk berkunjung.

\section{DAFTAR PUSTAKA}

[PHKA] Perlindungan Hutan dan Konservasi Alam. (2003). Pedoman Analisis Daerah Operasi Obyek dan Daya Tarik Wisata Alam (ADO-ODTWA). Bogor: Direktorat Jendral Perlindungan Hutan dan Konservasi Alam.

Aditiawati, P. Indriani, A. D. Suantika, G. \& M. Simatupang, T. (2016). Pengembangan potensi lokal di Desa Panawangan sebagai model desa vokasi dalam pemberdayaan masyarakat dan peningkatan ketahanan pangan nasional. Jurnal Sosioteknologi, 15(1), 59-67.

Devy, R.B. \& Soemanto. (2017). Pengembangan obyek dan daya tarik wisata alam sebagai daerah tujuan wisata di Kabupaten Karanganyar. Jurnal Sosiologi DILEMA, 32(1).

Dinas Komunikasi, Informatika dan Statistik. Kabupaten Kapuas Hulu. (2021). Potensi Obyek Wisata. www.kapuashulukab.go.id. [26 April 2021].

Eichhorn, V. \& Buhalis, D. (2011). Accessibility - a key objective for the tourism industry. IN Buhalis, D. \& Darcy, S. (Eds.) Accessible Tourism: Concepts and Issues, (pp. 46-61). Bristol: Channel View Publications. 
Erni Y. Rinekso, S. Hadi, S.A. \& Bambang, P.N. Analisis Potensi Ekowisata Heart Of Borneo di Taman Nasional Betung Kerihun Dan Danau Sentarum Kabupaten Kapuas Hulu. Jurnal Pengelolaan Sumberdaya Alam Dan Lingkungan. 8(1): 44-54.

Ghani, Y. (2015). Pengembangan sarana prasarana destinasi pariwisata berbasis budaya di Jawa Barat. Jurnal Pariwisata, II(2), 98-110.

Karsudi, R. Soekmadi, H. \& Kartodihardjo, (2010). Strategi pengembangan ekowisata di Kabupaten Kepulauan Yapen Provinsi Papua. Artikel IImiah. Jurnal Manajemen Hutan Tropika XVI (3), pp. 148-154.

Lidia, K. Fahrizal. \& Dirhamsyah. (2016). Penilaian potensi daya tarik obyek wisata danau Mupa Kencana Kecamatan Putussibau Utara Kabupaten Kapuas Hulu. Jurnal Hutan Lestari, $4(4), 472-477$.

Maharani, I. (2016). Analisis kelayakan potensi ekowisata pada kawasan wisata alam Bungi Kecamatan Kokalukuna Kota Baubau.

Paramita, M. Muhlisin, S. \& Palawa I. (2018). Peningkatan ekonomi masyarakat melalui pemanfaatan sumber daya lokal. Qardhul Hasan: Media Pengabdian Kepada Masyarakat, 4(1),19-30.

Saparuddin. (2010). Pemanfaatan air tanah dangkal sebagai sumber air bersih di kampus Bumi Bahari Palu. Jurnal SMARTek, 8(2), pp, 143-152.

Sumarabawa, I. G.A. Wesnawa, I. G.A. \& Astawa, I. B.M. (2013). Ketersediaan aksesibilitas dan sarana prasarana pendukung wisata pantai Pasir Putih Karangasem.

Undang-Undang Republik Indonesia Nomor 10.Tahun 2009 Tentang Kepariwisataan.

Wawan. (2011). Ekowisata Berkelanjuan. Yogyakarta: Gadjah Madah University Press.

Yuliani, Y \& Rahdriawan, M. (2014). Kinerja pelayanan air bersih berbasis masyarakat di Tugurejo Kota Semarang. Jurnal Pembangunan Wilayah \& Kota, 10(3),248-264.

Zaenuri \& Muchamad. (2012). Perencanaan Strategis Kepariwisataan Daerah: Konsep dan Aplikasi. Jogjakarta: e-Gov Publishing. 